Persp. Teol. 40 (2008) 181-205

\title{
UM CRISTIANISMO INÉDITO?
}

Mario de França Miranda SJ

Resumo: Numa primeira parte este artigo oferece aos leitores uma síntese da obra de Charles Taylor intitulada "A era secular", fiel à seqüência das partes do livro expostas pelo autor e ressaltando o que nos pareceu mais digno de nota. Numa segunda parte apresentamos uma reação pessoal à leitura desta importante obra. Aí aparece como as reflexões de Taylor incidem fortemente em algumas áreas da teologia e questionam seriamente o cristianismo convencional.

Palavras-chave: Cristianismo, Sociedade, Cultura, Secularização, Transcendência.

AвSTRACT: The article's first part offers to the readers a synthesis of Charles Taylor's "A secular era" according to the book's topics presented by the author highlighting what is important to note. In the second part we introduce a personal response to this important work. There appears how Taylor's reflections strongly involve some areas of Theology and raise serious questions about the conventional Christianity.

KeY-woRDs: Christianity, Society, Culture, Seculatization, Transcendence. 


\title{
Introdução
}

\begin{abstract}
s profundas mudanças de cunho sociocultural que sacodem o planeta atingindo instituições como a família, a universidade, a organização política, a vida econômica, também não deixam de fazer sentir seus efeitos no âmbito da religião. Já se afirmou que a velocidade de tais transformações não permite às instituições se adequarem aos novos desafios que surgem, gerando assim em todas elas um mal-estar sentido por todos nós como manifestação de uma crise que não conseguimos definir com precisão. Na Igreja Católica este descompasso foi pressentido por João XXIII antes mesmo dos acontecimentos de maio de 1968. De fato, o Concílio Vaticano II procurou um aggiornamento da Igreja através do diálogo com a sociedade, com a cultura, com outros cristãos e mesmo com outras religiões. Deste modo mudanças foram efetuadas, embora intuições importantes tenham permanecido sem dar frutos por razões várias, algumas delas provindas da própria Igreja. De fato, mais facilmente mudam as idéias do que se transformam as instituições.
\end{abstract}

Mas a evolução sociocultural não se deteve nesta época e hoje já se aponta para a necessidade de correções e atualizações de textos-chave da Constituição Apostólica Gaudium et Spes. A maior sensibilidade para com as culturas nativas, as conseqüências do reconhecimento da liberdade religiosa, a crescente consciência de cidadania e de vontade de participação política, a crise ecológica, a globalização econômica e cultural em curso no planeta, a emergência inédita de uma sociedade secularizada afetando grande contingente de nossos contemporâneos são alguns exemplos dos novos elementos que transformam o cenário social e que acabam por repercutir no interior das instituições religiosas.

A atual situação da sociedade em sua relação com o mundo religioso tem provocado estudos das mais diversas procedências, todos eles buscando esclarecer o emaranhado dos diversos elementos em questão pela análise dos mesmos a partir de suas respectivas chaves de leitura. Na área da historiografia Jean Delumeau ${ }^{1}$ e René Rémond ${ }^{2}$ são nomes bem conhecidos. Numa perspectiva mais sociocultural as obras de Peter Berger ${ }^{3}$, de

\footnotetext{
${ }^{1}$ Un christianisme pour demain, Paris, 2005, que reúne seus dois livros: Le christianisme va-t-il mourir?, Paris, 1977 e Guetter l'aurore, Paris, 2003.

${ }^{2}$ Religion et société en Europe, Paris, 1998 e Le christianisme en accusation, Paris, 2000.

${ }^{3}$ É o mais conhecido no Brasil por sua obra $O$ dossel sagrado, S. Paulo, ${ }^{2} 1985$. Mas devemos acrescentar outros livros seus como A Far Glory. The Quest for Faith in an Age of Credulity, New York, 1992, The Desecularization of the World: Resurgent Religion and World Politics, New York, 1999 e Questions of Faith, Oxford, 2004.
} 
Franz-Xavier Kaufmann ${ }^{4}$, de Danièle Hervieu-Léger ${ }^{5}$, de José Maria Mardones $^{6}$ e de João Batista Libanio ${ }^{7}$ demonstram o interesse pela questão. Uma interpretação atenta às idéias subjacentes que influem na vida da sociedade atual aponta nomes como o de Marcel Gauchet ${ }^{8}$ e de Paul Valadier'. Mais recentemente, na trilha dos grandes pensadores que marcaram o Vaticano II, como Henri de Lubac, Karl Rahner, Yves Congar, entre outros, o viés teológico desponta na obra de Cristoph Theobald ${ }^{10}$.

É dentro deste contexto marcado pela instabilidade das mudanças, pela análise diversificada da realidade sociocultural e pela busca ansiosa de orientações para o futuro que surge a volumosa obra de Charles Taylor às voltas com a mesma temática ${ }^{11}$. O autor pretende refletir sobre a situação do cristianismo ocidental numa sociedade secular. Para ele o processo histórico de secularização apresenta três sentidos. Partindo-se das sociedades mais antigas, onde toda a realidade social estava profundamente entranhada pela religião, a primeira etapa da secularização implicou na emergência de espaços públicos sem referência ou dependência de verdades religiosas, tais como hoje experimentamos na área científica, política, econômica, etc. Podemos também entender a secularização como uma queda na fé e na prática religiosa por parte das pessoas, fenômeno que também pode ser observado em nossos dias em alguns países ocidentais. Contudo o autor pleiteia um terceiro sentido para a secularização, ainda conexo com os dois precedentes e que constitui seu objeto de estudo. Trata-se de uma sociedade onde a fé em Deus deixou de ser algo partilhado por todos, onde o que crê se encontra rodeado por pessoas que vivem corretamente sua vida familiar, profissional, ou cidadã sem uma referência a Deus ou a uma realidade transcendente, fato este que poderá desafiar bastante sua própria

\footnotetext{
${ }^{4}$ Religion und Modernität, Tübingen, 1989.

${ }^{5}$ Entre os principais: Vers un nouveau christianisme?, Paris, 1986, La religion pour mémoire, Paris, 1993, Le pélerin et le converti, Paris, 1999 e Catholicisme, la fin d'un monde, Paris, 2003.

${ }^{6}$ Entre outras: Postmodernidad y cristianismo, Santander, 1988, Las nuevas formas de religión, Estella, 1994, Adónde va la religión?, Santander, 1996, Neoliberalismo y religión, Estella, 1998.

${ }^{7}$ Qual o futuro do cristianismo?, S. Paulo, 2006.

${ }^{8}$ Le désenchantement du monde, Paris, 1985 e La réligion dans la démocratie, Paris, 1998.

${ }_{9}^{2}$ L'Église en procès, Paris, 1989 (tradução brasileira: Catolicismo e sociedade moderna, S. Paulo, 1991), Un christianisme d'avenir, Paris, 1999, Morale en désordre, Paris, 2002, La condition chrétienne, Paris, 2003 e Détresse du politique, force du religieux, Paris, 2007.

${ }^{10}$ Le christianisme comme style t.I et t.II. Une maniére de faire de la théologie en postmodernité, Paris, 2007, Transmettre un Évangile de liberté, Paris, 2007.

${ }^{11} \mathrm{CH}$. TAYLOR, A Secular Age, Cambridge, 2007. Este autor já escrevera: Sources of the Self. The Making of Modern Identity (1989), The Ethics of Authenticity (1992) e Varieties of Religion Today (2002), todos pela Harvard University Press.
} 
fé. Pois se trata de um fato inédito na história da humanidade, já que a descrença, mesmo defendida por uma certa elite, nunca foi patrimônio das outras camadas da sociedade.

A era secular irá acarretar novos desafios não só para os cristãos, convivendo no futuro com pessoas descrentes dotadas de moral e mesmo de espiritualidade, mas também para o próprio cristianismo, privado de um suporte social que lhe conferia maior credibilidade. No primeiro caso mudam-se as condições para a fé do indivíduo; no segundo, se pressiona o cristianismo a buscar uma nova configuração histórica. O livro de Charles Taylor procura apontar os fatores que contribuíram para o aparecimento da atual sociedade. Conhecendo a complexidade da temática e embora seguindo em grandes linhas uma seqüência cronológica, ele apresenta estas causas como "relatos", que em seu conjunto poderiam explicar a gênese da sociedade secularizada.

\section{A Era Secular}

\section{Parte I: A obra da Reforma}

Dividido em cinco partes, das quais a primeira vem intitulada "A obra da Reforma", o autor examina num capítulo inicial o que denomina as muralhas da fé, expondo uma questão que irá acompanhá-lo por todas as páginas: por que era tão difícil há 500 anos atrás alguém não crer em Deus e por que hoje não o é mais $(25)^{12}$ ? E apresenta três razões: o mundo era visto como um cosmo ordenado e sob as ordens de Deus, toda a existência humana na sociedade estava entranhada de Deus e o povo vivia num mundo "encantado" com espíritos e demônios (25s). O progressivo desaparecimento destes dados se alia a uma outra razão de peso, a saber, a possibilidade de uma aspiração ou motivação moral independente de Deus, o que implica grande confiança do ser humano em si próprio (26s). O autor não aceita ver nesta gênese histórica da atual sociedade uma diminuição de cunho negativo com relação à sociedade passada, especialmente enquanto fortemente determinada pelo fator religioso. A refutação desta interpretação da modernidade, já considerada comum, será um dos objetivos de sua obra (29).

A primeira muralha da fé é o mundo encantado dos espíritos. Observa primeiramente que ao afirmar que não os experimentamos como outrora, não significa que eles não existam, afirmação esta que vale até para Deus (31). Mas esta mudança é muito importante. Pois no mundo encantado do

${ }^{12}$ Os números entre parênteses se referem às páginas do livro. 
passado estavam presentes espíritos bons e maus como uma realidade não meramente subjetiva, mas realmente existentes. Uns espíritos buscavam prejudicar as pessoas levando-as a apelar aos outros (bons) para deles se livrar (32). Tais espíritos atuavam de fato, tinham poder de curar enfermidades, salvar navios na tempestade, evitar desastres. Também determinados objetos gozavam de força especial, como as relíquias, a hóstia, os círios abençoados. Havia de certo modo uma mentalidade mágica difusa e atuante na experiência humana e na consciência das pessoas, que se viam então vulneráveis a tais poderes (35s). O indivíduo tinha o que o autor chama de "personalidade porosa" (porous self) a tais influências. Não havia como hoje uma clara linha de demarcação separando o físico do moral (40). Naturalmente um tal contexto tornava inviável qualquer tentativa de descrença (41), pois esta significava ameaça à vida cotidiana por atingir bases aceitas da convivência social (42). E Deus se encontrava fundamentando a sociedade, portanto era absurdo duvidar de sua existência (43).

Outro ponto mencionado por Taylor diz respeito à tensão, encontrada segundo ele nas grandes religiões, entre uma vida voltada para valores transcendentes e uma vida dirigida a realizações humanas normais. Faziase mister encontrar um equilíbrio entre ambas. Para ele esta solução dividiu o cristianismo em duas classes de pessoas, a saber, o clero e o laicato, cada uma delas com uma função na sociedade que complementava a outra (44). A tensão também se manifestava no modo como o sagrado era utilizado para fins "profanos", costume fortemente criticado por Erasmo (45). Ainda a existência de tempos especiais, como o carnaval, que atuavam como válvula de escape para o cotidiano marcado pela fé, é um outro exemplo de solução para a mencionada tensão (45-50).

Também a concepção do tempo no passado era fortemente marcada pelo sagrado. As festas litúrgicas e as celebrações religiosas estruturavam os meses do ano, trazendo certa ordem ao tempo vivido e tornando mais próximos eventos de um passado remoto, como a paixão e morte de Jesus Cristo na semana santa, do que acontecimentos do ano anterior (57s). Hoje vivemos um tempo uniforme, unívoco, secular (59). Ainda deve ser mencionada a mudança da idéia do cosmo, entendido como uma totalidade ordenada afetando a vida dos humanos, para a concepção moderna de universo, fruto da revolução científica, sucessão de eventos dentro das leis da natureza, sem um começo e um fim definidos e com uma extensão que supera nossa imaginação. Apesar dos choques iniciais com o imaginário presente na Bíblia, esta nova representação do universo dentro de uma ordem bem regular não implica munição para a descrença, pois irá alimentar certa idéia de providência de Deus (61).

Entre as causas de toda esta transformação da sociedade o autor aponta uma como a mais importante: a Reforma (61). Nasceu do grande mal-estar provocado pelo equilíbrio precário entre os mais e os menos comprometi- 
dos religiosamente numa sociedade altamente hierarquizada, fenômeno recorrente nas grandes religiões. Ela foi precedida por tentativas de reformas (com erre minúsculo) (62s), quando leigos também procuravam uma espiritualidade mais pessoal e uma religião que não se reduzisse a práticas devocionais (71). Para o autor estas práticas voltadas em grande parte para benefício próprio pressupunham uma mentalidade mágica e pretendiam controlar a ação de Deus (72s). Nesta situação desempenhou papel importante a "pastoral do medo" que acentuava o pecado e a danação eterna, gerando ansiedade e angústia (75). Aqui se entende, para o autor, o sucesso de Lutero com sua teologia da salvação pela fé. O sagrado não pode se prender a objetos, espaços, tempos, ritos ou pessoas (76.79). Pela fé todos estão em igual situação e a soberania de Deus é total. Deste modo a Reforma ataca o cosmo encantado e oferece uma alternativa humanista para a fé (77). Contudo, o pessimismo dos reformadores com relação à situação pecaminosa do ser humano, enquanto entendida dentro de um horizonte de compreensão fortemente jurídico-penal, irá afastar as pessoas da fé e lançá-las em direção ao deísmo (78s). Mas ao concretizar a vida cristã no cotidiano, a todos acessível, a Reforma promove a confiança na criação de uma ordem que resulte numa sociedade querida por Deus. Entretanto, se o objetivo da ordem é esta realização humana, Deus pode desaparecer do horizonte. Se formos capazes de efetuá-la, então não mais a recebemos de Deus. Aqui já desponta o humanismo fechado de nossos dias (84).

O capítulo seguinte trata da ascensão de uma sociedade disciplinadora. Em geral o processo de secularização é visto como uma diminuição da presença de Deus (90) pelo crescente interesse no estudo da natureza. Errado, diz o autor, pois neste tempo a idéia da criação como obra de Deus era muito forte, de tal modo que o conhecimento da natureza significava também conhecer o desígnio de Deus (91), desvendar a linguagem da realidade era mostrar o que possibilitava a linguagem de Deus na Bíblia (92). Deus falava também na natureza e o novo interesse por ela se dava no interior de um quadro religioso (95). O advento do nominalismo defendendo a "vontade absoluta" de Deus (97) rompe esta correlação: os fins da natureza não estão nela, mas provêm de fora (Deus, homens). Deste modo, ela não é mais normativa. Depende da racionalidade funcional levar as riquezas da natureza efetivamente aos desígnios de Deus, que não mais se faz presente por seus "sinais" como acontecia na visão clássica do cosmo ordenado (98). Acrescenta-se a estes fatores o Renascimento, que procura ordenar o mundo pela razão (ciência) e pela imaginação (arte) (99). Papel importante desempenha nesta época a noção de "civilidade", afim à nossa idéia de civilização (99s), que implica paz doméstica e possibilidade de desenvolvimento comercial (101) numa população disciplinada (101.103). Aqui muito ajudará a reforma calvinista advogando a igualdade de todos e abolindo classes de pessoas (104), exigindo "civilidade" de todos e tornando-os elementos úteis para a sociedade (111). Grande influência teve Justus Lipsius que cria uma espécie de neoestoicismo cristão (115). Deus é 
a fonte da razão, mas o que esta pretende é a realização do ser humano. Prepara-se assim o próximo passo para o posterior deísmo (117). O projeto calvinista visava a uma sociedade sem desordens e violência e constituída por uma população disciplinada (119), o que implicava grande confiança no ser humano (121). Houve assim uma mudança no horizonte de compreensão (123), na noção de lei natural, agora obtida pelo consenso racional dos atores sociais (125s). Esta lei é a base para a paz (127) bem como para o desenvolvimento econômico na sociedade (129). O processo de secularização se mostra assim bem complexo (143).

No capítulo seguinte, mais breve, Charles Taylor se ocupa com a grande liberação (The Great Disembedding). Assim chega ao fim a tensão própria de uma sociedade hierarquizada através da reforma (146), do primado do indivíduo (146), embora ainda dependendo do contexto social que lhe fornece sua identidade (149). Mas o relacionamento com a divindade, ao contrário das religiões arcaicas onde se dava sempre através da sociedade, acontece diretamente. Também delas divergindo, o objetivo do cristianismo vai além de uma mera realização humana (151ss). A caridade cristã, entretanto, se vê reduzida a uma moral que institui uma sociedade disciplinada (158).

Segue-se o capítulo dedicado aos imaginários sociais modernos. Grande força atribui o autor à ordem moral entre indivíduos, da qual se derivam as obrigações de cunho político (159), não mais fundadas em bases religiosas, mas no consenso de todos como fundamento de sua legitimidade (160). A noção de ordem moral não só regulamenta a vida social, mas transmite uma nova consciência de que suas normas correspondem ao desígnio divino e à vida humana normal. Surge como um contexto que facilita sua aceitação (162s). Distingue-se ela das antigas ordens, provindas de "tempos imemoriais" e fortemente hierarquizadas (163s). A hierarquia, como também qualquer estrutura de diferenciação, perde assim sua base ontológica. A nova ordem é de cunho funcional, pois seu objetivo é simplesmente a segurança e a prosperidade, embora não seja pensada como mera invenção humana já que corresponde à vontade de Deus (166). Surge assim um novo imaginário social que afeta a vida em todos os seus setores (167). A rejeição de uma ordem hierárquica irá acentuar a importância do indivíduo; a idéia de que se deve buscar a paz e o mútuo benefício irá valorizar a economia como fator social; a centralidade do indivíduo, ao qual serve a política, irá valorizar a noção de direitos humanos (170s).

O imaginário social abrange a linguagem, a compreensão, as aspirações, partilhadas por todos e transmitidas em imagens, histórias, lendas, etc. Tal imaginário é o que possibilita práticas coletivas (171s). A nova ordem moral influencia o imaginário social (175), a começar pela noção de providência de Deus (177) e da importância da economia para a paz e a prosperidade $(178 ; 181)$. A Reforma fomentando uma sociedade disciplinada atua como um fator importante na metamorfose do imaginário de então (179). Tam- 
bém o surgimento da "esfera pública", espaço comum fora do âmbito político, manifestado na "opinião pública", e com poder de legitimação contribui para mudar o imaginário social (185-188). Cresce com a ascensão cultural da população (188) e tem na razão, e não em Deus ou na lei da natureza, o seu fundamento (190). Surge assim um imaginário que o autor caracteriza como "secular" no sentido que não provém de Deus, ou de uma tradição imemorial, mas simplesmente da razão (192), não reconhecendo qualquer instância que a transcenda (194). Deste modo o povo se torna soberano (196) e a sociedade menos hierarquizada e mais horizontal se torna uma sociedade de acesso direto (207-209). Esta parte termina num breve capítulo (o espectro do idealismo) no qual Taylor se defende da acusação de ser um idealista, que desconsiderasse os fatores materiais de uma evolução histórica ou do surgimento de um novo imaginário social (212s).

\section{Parte II: O ponto de transição}

A segunda parte da obra começa tratando da providência divina numa ótica deísta. A noção tradicional de divina providência irá sofrer uma diminuição em seu sentido, já que toda voltada para a realização humana na sociedade (221). Houve sérias mudanças antropocêntricas nos séculos XVII e XVIII que a explicam. Devemos a Deus apenas ter que levar a cabo o seu plano que é o nosso próprio bem, podemos consegui-lo com a razão e a disciplina (eclipse da graça divina), a vontade divina está implícita na ordem natural dispensando a existência de mistérios, o desígnio de Deus não transcende a realidade terrena (omite-se a felicidade eterna com Deus nesta concepção da divina providência) (222-224). Este quadro imanente se fortalecerá pelo papel crescente da economia na sociedade: uma vida produtiva, pacífica, ordenada é vista como vida modelar (229). Deus permanece ainda apenas como nosso Criador e, portanto, nosso benfeitor a quem devemos gratidão sem medida. Porém, em segundo plano, pois sua vontade conhecida pela razão transforma o culto que lhe é devido em realizar o nosso bem individual e social; por outro lado, uma ética laical que fomenta a ordem social dispensa a graça divina (233s). Aparece assim uma ordem social marcada por um ideal de civilização e caracterizada pelo respeito à liberdade e à opinião dos outros, pela compreensão que o intercâmbio social beneficia a todos, pelo lugar de honra dado ao comércio e às atividades produtivas (236s). Esta ordem moral como fruto de uma sociedade educada independe da ação e do controle das Igrejas, podendo ser vivida sem referências a realidades transcendentes (239). Podem-se constatar assim decisivas "mudanças antropocêntricas" neste período: Deus se torna uma realidade secundária porque a ordem social almejada pode ser alcançada apenas pelo esforço humano, a realização moral é vista de modo puramente imanente, a motivação para alcançá-la é a idéia do beneficio de todos (244s). A benevolência ganha um status universalista, sem referência a Deus. O humanismo se volta todo para a realização humana com ênfase na razão 
instrumental (247). A Reforma ajudou o processo porque, ao colocar a vivência cristã na vida cotidiana, valorizou a vida, a prosperidade, a paz e o benefício mútuo (266). O que vimos demonstra que não podemos conceber a descrença ou o humanismo exclusivo como mera realização da razão sem uma referência, implícita ou não, às crenças anteriores (269).

A ordem impessoal, tema do capítulo seguinte, aborda um dos fatores decisivos para o atual humanismo exclusivo ou imanente. Pois transformará o Deus que interage com os humanos e atua na história num Deus arquiteto do universo e apenas atuante nas leis imutáveis da natureza (270). O autor menciona ainda o "desencantamento" e a concepção moderna de história (271). Estes vários fatores já demonstram que reduzir todo o processo a uma conquista da razão e da ciência sobre a religião não faz jus à verdade, embora representações tradicionais de Deus possam ter cooperado para isso. Pois se trata, isto sim, da confluência de várias causas que produzem um horizonte de compreensão responsável pela interpretação reducionista de que Deus não age na história (274s). A fé cristã já teve que lutar na era patrística com modos de pensar gregos que contrariavam os dados da revelação. O sentido do corpo, da história, do indivíduo, da contingência e das emoções (coração), de um Deus pessoal que nos ama (275-279). Todos estes itens envoltos num contexto de comunhão são reinterpretados numa ótica que proíbe qualquer intervenção de Deus, vista sempre como milagreira (280). Além disso, o conhecimento científico aparece como modelo de conhecimento por "objetivar" a realidade e não envolver o sujeito que conhece (285), sendo exportado ideologicamente para qualquer tipo de abordagem da realidade (286). O moderno deísmo incorpora as transformações efetuadas na patrística, mas priva-as de sua relação com Deus (288). Daí nasce um horizonte de interpretação, fortemente alimentado pela ordem impessoal (cósmica, social e moral), pelo prestígio moral de uma instância "objetiva" e pelo desprezo das elites com relação à religiosidade popular (288). Daí o cristianismo ser olhado como realidade do passado a ser superada nos dias atuais (289). Advoga-se então uma "religião natural", não revelada, que relativiza as religiões históricas, pois Deus já pode ser encontrado pela razão na ordem impessoal que rege o mundo (292s). Daí, conclui o autor, que o deísmo implica numa nova maneira de olhar a realidade (293), numa pré-compreensão que atua, seleciona e interpreta os dados oferecidos (294). Esta matriz mental explica o processo para o deísmo e situa os que crêem e os que não crêem num novo contexto (295).

\section{Parte III: $O$ "efeito nova"}

Segue-se uma terceira parte da obra que trata de diversas reações à modernidade, chamadas pelo autor de "efeito nova", presente entre as elites e posteriormente atingindo toda a sociedade, e estendendo-se até 
metade do século XX. Num capítulo inicial ( $O$ mal-estar da modernidade) expõe a cultura da "autenticidade", ou do individualismo expressivo, que estimula as pessoas a encontrar seu próprio caminho. Diminui assim o elo entre uma vida espiritual e a pertença a instituições como o Estado ou a Igreja (299s). A modernidade implica educação, autodisciplina, governo, respeito às leis, civilidade. Mas enquanto ancorada numa ordem social e num tempo secularizado, ela é experimentada como um limite que nos torna cegos ou insensíveis ao que se situe além deste mundo ordenado. Daí um certo mal-estar ocasionado por este mundo desencantado, sentindo-o como plano e vazio (301s). Além disso, o humanismo imanente provoca a questão pelo sentido da vida ou pelo sentido dos sentidos parciais, que se nos afiguram frágeis e incertos (308). Buscam-se soluções para preencher o vazio, mas que sejam imanentes. Surgem novas formas de religião ou leituras diferentes da imanência (fenômeno nova) (310). Nos capítulos seguintes trata da transformação da noção do tempo, o escuro abismo do tempo (322-351), do mundo da descrença em expansão (352-376), finalizando com o que chama de trajetórias do século XIX, encontradas especialmente nos filósofos e literatos (377-419).

\section{Parte IV: Narrativas de secularização}

Nesta quarta parte do livro Charles Taylor procura mostrar mais em concreto sua tese de que o processo de secularização não se deu linearmente provocado pela diferenciação ocorrida na sociedade. Um primeiro capítulo (A era da mobilização) aborda esta questão afirmando que a diferenciação não implica sem mais a secularização, pois os diversos setores que emergem podem seguir influenciados pelo cristianismo, desde que moldado em outras formas (425). Não se pode negar um declínio na prática e na crença religiosa em muitos países, ou no desaparecimento de Deus no espaço público. Mas a secularização, ao contrário do que comumente se entende, não significa declínio da religião. Podemos mesmo questionar o passado como a idade de ouro da religião (426s). De qualquer modo pesa nesta questão o horizonte de compreensão de cada estudioso, que só no diálogo com outros horizontes poderá cair na conta de seus limites e corrigir suas distorções (428). Para o autor a secularização se deve a um processo de transformação da sociedade, já mencionado anteriormente. A saber, a realização humana como objetivo mais alto da sociedade no interior de uma ordem moral e de um comércio atuante motivado pela idéia de que a participação de todos resulta num benefício mútuo (430). Esta sociedade transformada é que questiona não a religião, mas as formas arcaicas da mesma (432). Deste modo fatores como a urbanização, a migração, a industrialização, provocam a criação de novas modalidades religiosas (437).

A sociedade do "ancien régime" era fortemente hierarquizada, fundamentada na vontade divina e nas leis ancestrais, onde cada um tinha seu lugar 
determinado que o relacionava com o todo social (438). Era também um mundo "encantado" (Max Weber), no qual o sagrado estava bem localizado em lugares, pessoas, dias e festas (446). Com a transformação social em curso as Igrejas se mobilizam para se adaptar ao novo cenário. Deste modo procuram que Deus se torne presente em toda a parte do tecido social, pois realizar seu desígnio é o objetivo da sociedade, definindo assim também sua identidade política. O segundo passo foi o aparecimento das "denominações eclesiais" que se reforçam mutuamente em vista do objetivo comum, como aconteceu nos Estados Unidos (453). Esta mobilização para uma identidade religioso-política determina o presente da religião e talvez o seu futuro (459). O autor volta a contrapor com muita clareza as características da sociedade pré-moderna e da sociedade da época da mobilização (459s), insiste na sua tese contra a teoria unilinear da secularização, observando como o que se deu diversamente nos Estados Unidos e na França a debilitam profundamente (461). Na época da mobilização (1800 a 1950) muitas formas religiosas do período anterior decaíram ou desapareceram, mas novas formas surgiram adaptadas à época e concernentes à espiritualidade, à disciplina, à identidade política e a uma imagem da ordem civilizadora (472).

Segue-se o capítulo dedicado às manifestações da pós-modernidade, opostas de certo modo à etapa anterior e que se intitula a era da autenticidade. Começa na segunda metade do século XX como fenômeno de massa (473), embora já tenha emergido entre a elite da sociedade na época do romantismo. Cada um deve seguir seu próprio modo de vida visando ao que o faz feliz, e não se submeter a modelos vindos da sociedade, da tradição ou de alguma autoridade política ou religiosa (475). Trata-se de uma rejeição à ordem anterior, disciplinada, repressora da criatividade individual, sujeita à racionalidade funcional e a resultados palpáveis (476). Há o perigo de se buscar uma satisfação pessoal limitada que invalida outros objetivos e confina a ordem moral a um fragmento seletivo (478). Deste modo certas noções sofrem diminuição de seu conteúdo semântico, como "escolha", "liberdade", "direitos", "respeito", "não-discriminação" (479). Também observa o autor que estamos às voltas com um fenômeno ambíguo, pois para seus críticos é a afirmação da sensualidade, do egoísmo, da busca de prazer, do consumismo, sem ter em consideração suas conseqüências (480). A busca da felicidade individual já existia no passado, mas emergia sempre dentro de um contexto de respeito mútuo, de ética civil, de certos valores de família, de trabalho e de produtividade que, hoje, sofrem um processo de erosão visível (485).

Taylor distingue três épocas distintas, nas quais o indivíduo se relacionava com o sagrado e que constituíam imaginários sociais diferentes. Na primeira o elo se dava através da Igreja, co-extensiva à sociedade, elo este que se impunha ao indivíduo. Na segunda existe maior liberdade de se escolher uma "denominação" (Igreja), sendo a coerção uma realidade inimaginável. Na terceira, caracterizada pela auto-expressão, a escolha não 
mais se prende a uma Igreja ou a uma doutrina, mas busca um caminho espiritual que se mostre mais adequado. Três "tipos ideais" que não se encontram como tais na realidade, já que podem conter outros componentes, mas que apontam para uma transformação histórica na relação da pessoa com Deus (486-488). Num cristianismo marcado pelo racional e pela ortodoxia doutrinal, a pessoa julga só poder se relacionar com Deus através de um forte sentimento, de uma paixão. A intuição pessoal profundamente experimentada se torna a mais preciosa fonte espiritual (488s). Este quadro atual que rejeita a disciplina, o autocontrole, o mútuo benefício através da participação de cada um, traz um sério problema para as Igrejas que mantêm uma ordem ética e o respeito a uma tradição (autoridade) religiosa, ambas rejeitadas pela atual juventude (493).

O capítulo seguinte que aborda a religião hoje procura mostrar de modo positivo como a juventude em nossos dias busca uma experiência direta com o sagrado, valoriza a espontaneidade e a espiritualidade, já que profundamente insatisfeita com uma vida enclausurada numa ordem imanente, que lhe aparece como vazia, plana, desprovida de uma finalidade mais elevada. Mas esta juventude se situa depois da revolução expressiva da segunda metade do século passado e, portanto, almeja totalidade (holismo), valorização do corpo e dos sentimentos (506s). A cultura privilegia o indivíduo e sua experiência, e a espiritualidade, enquanto se contrapõe à religião (instituição), deve falar para esta experiência que tem algo de uma exploração autônoma, não mais rendida à autoridade, e menos ainda ao moralismo e juridicismo encontrados nas Igrejas (507ss). Para o autor a religião se caracteriza por um duplo critério: fé numa realidade transcendente e aspiração a uma transformação que ultrapassa a realização humana ordinária (510). Daí observar que esta mencionada espiritualidade pode se revelar superficial e limitada ao "sentir-se bem", um desvio entre outros que já aconteceram no passado (512s). A diminuição das práticas religiosas e o enfraquecimento das instituições não representam decadência da religião, mas crise de uma sua configuração histórica, a saber, da cristandade (514). Uma nova modalidade irá surgir com características que já emergem: meditação, envolvimento em obras de caridade, grupo de aprofundamento da fé, peregrinação, modalidades especiais de oração (515), bem como modalidades diversas de adesão religiosa (516).

Taylor distingue sempre o quadro interpretativo dos conteúdos do mesmo. Assim o primeiro pode ser imanente, mas não o segundo, o que explica a sobrevivência da religião (transcendência) numa sociedade secularizada (imanência) (518). Característica também em nossos dias é a religiosidade distante (believing, but not belonging) (522). A secularização não significa, portanto, regressão da religião, mas crise de sua modalidade tradicional, já que o desejo de eternidade permanece (530). O futuro do cristianismo está menos nas instituições quanto em fortes intuições de indivíduos que as possam irradiar para outros. Embora menos envolvido no espaço público, sua 
proclamação salvífica será aí mais intensa (532). Vivemos uma época de transformação e de busca do "espiritual" e não tanto "do religioso" (535).

\section{Parte V: Condições da fé}

Na quinta e última parte da obra Taylor trata das "condições dos que crêem". Começa abordando, num capítulo longo, o horizonte fechado à transcendência, próprio de nossos dias em muitos países. Neste a pessoa se acha interiormente impermeável a agentes de fora (espíritos, forças morais, poderes). Tudo o que a pode afetar provém de si mesma (539). Além disso, ela se move num espaço social construído, sobretudo pela racionalidade funcional e num tempo linear e secular (542), sendo que tal contexto pode ser mesmo matéria de experiência (543). Entretanto podem ser verificadas diversas reações críticas a esta visão utilitária (545). De fato, no interior deste horizonte fechado o que o transcende pode ser considerado ou como ameaça à obtenção de um bem maior ou, simplesmente, a resposta a um desejo ardente do ser humano (548). Para o autor, as diferentes opções dependem de uma compreensão, de uma confiança anterior, que abre alguns setores da realidade e que esconde outros (550s). De qualquer maneira notase hoje um sentimento de vazio, de uma perda de sentido (552).

Por outro lado, o sagrado se deixava experimentar no passado em lugares, tempos, pessoas e ações determinadas. Depois com o processo de desencantamento tal não mais acontece com a mesma intensidade. Não se trata de um declínio da religião, mas da mudança de uma forma religiosa para outra, cuja ligação com Deus acontece por intermédio de interpretações pessoais (553s). Daqui conclui o autor que, embora o quadro atual seja fechado à transcendência, crer ou não crer dependerá do horizonte de compreensão de cada um (556). Este horizonte é descrito como uma cosmovisão que terá grande influxo no modo como vemos e julgamos a realidade (557s). Assim o que parece óbvio no sistema fechado ou imanente, não o é tanto quando se examinam seus pressupostos, como a primazia do individual, do neutro, ou do subjetivo como locais de certeza. Igualmente uma certa ética aí embutida como independente, controladora, responsável, que não cede aos confortos da obediência a uma autoridade ou às consolações de um mundo encantado. São valores que se apresentam desencadeando todo o processo, operando desde o início. Mas se assumimos um outro horizonte de compreensão, o que parecia óbvio desaparece. Pois o que se apresentava como "natural", de fato resultou de uma criação histórica da identidade humana, a saber, do sujeito não comprometido, objetivo. Como se fosse um passo adiante que o libertaria dos mitos ou ilusões anteriores, devidamente ultrapassados (559s).

A mesma desconstrução pode ser efetuada com relação ao argumento moral que pleiteia para o que não crê uma atitude de maturidade, de coragem e de honestidade, conquistada muitas vezes pelo abandono de uma fé 
infantilizada devido aos posteriores conhecimentos científicos. Esta visão ética, não natural, mas construída, reprime tendências mais profundas, entre elas a da fé religiosa (562s). Assim conclui Taylor estar convencido de que não se trata da "morte de Deus", nem da ciência (cuja neutralidade constitui um mito), mas das atuais e difíceis condições para a fé (564). O pacote subjacente à atual descrença que abrange a pessoa "protegida" de influxos externos (espíritos), o individualismo moderno, a razão instrumental, o tempo secularizado acaba por constituir o horizonte fechado que será acolhido sem mais ou criticado conforme a interpretação de cada um (566). Este horizonte não explica porque, reduzido somente à busca de realização e felicidade meramente humanas, possa justificar o anseio por justiça universal e não somente pela minha própria e de meus familiares (572). Com isto descarta a teoria da "diminuição" aventada pelos ateus (573).

O capítulo seguinte intitulado pressões cruzadas trata da situação de fragilidade das diferentes religiões bem como da crença e da descrença (595). Assim o humanismo imanente é questionado por três questões básicas: como explicar a força específica de uma instância criativa, as exigências éticas e a força das experiências artísticas, sem falar em termos de uma realidade transcendente que nos interpela? (597) Taylor é de opinião que as pessoas hoje estão em posições intermédias, evitando os extremos do dilema religião transcendental ou materialismo redutor (598). Nos dois capítulos que dão seqüência a este o autor discute vários dilemas presentes na atual discussão: desprezo do corpo, leitura meramente psicológica do mal e do pecado (618-620), acusações feitas à religião por prejudicar a realização humana pelo ascetismo e pela renúncia ao almejar bens "superiores" e por não aceitar a realidade humana imperfeita com a agressividade e o conflito nela embutidos (623s).

No penúltimo capítulo intitulado as fronteiras inquietas da modernidade Taylor se coloca como um observador imparcial que busca outras fontes de sentido para os diversos setores da vida (711). Assim a sociedade hoje demonstra não se satisfazer com o quadro fechado da cultura imanente. Nota-se a busca de sentido para a vida, uma compreensão mais profunda e quase sagrada da natureza, a linguagem artística como apontando para algo transcendente, o fato da morte como a negação do significado do amor ou como saída dos limites desta vida (726). A situação da fé em nossos dias é difícil, pois a cultura marcada por um individualismo "expressivo", fragmentada, abrangendo uma multiplicidade de posições, leva a um declínio das grandes linguagens da transcendência com a busca individual de felicidade definida pela cultura do consumo ou obstaculizada pela ameaça do desemprego e da pobreza. Por outro lado, muitos estão inquietos se perguntando em momentos de reflexão pelo sentido de tudo isso, mesmo entre os incrédulos, que admiram uma Madre Teresa de Calcutá ou qualquer figura que encarne com autenticidade os valores cristãos. Tal é a estranha e complexa condição da fé em nossa época (727). 
Finalmente a obra termina com um capítulo intitulado conversões, quando se observa que estas implicam uma mudança do quadro interpretativo onde as pessoas pensam, sentem e vivem. Tal mudança traz elementos que vão além das fronteiras do quadro, fazendo com que as coisas obtenham sentido de um outro modo. Tal se passa com as conversões em nossos dias, por exemplo, de uma perspectiva terapêutica imanente para outra espiritual (730s). Por outro lado o autor examina o que pode desencadear tais conversões e aponta entre outras causas para o vazio experimentado pelo homem moderno "que sabe o preço de tudo e o valor de nada, e que perdeu a capacidade de sentir ou de pensar em profundidade sobre qualquer tema" (734). Contudo, não podemos vislumbrar o modelo de cristianismo do futuro, sendo que a cristandade permanece sempre como uma referência (734s). Taylor aceita a crítica de Ivan Illich que vê o cristianismo transformado num conjunto de preceitos morais universais, quando ele é, de fato, um novo modo de existência que envolve nova motivação e nova modalidade de comunidade (738). Tudo deveria consistir numa rede de amor (ágape) com a exigência de nos aventurarmos em novas relações. Não conseguindo realizá-las, as institucionalizamos, criamos regras e executamos obras de caridade. Agimos racionalmente buscando eficácia conforme as modernas burocracias, deixando em segundo plano o indivíduo. Falta a comunhão vital celebrada na eucaristia (738-740). A parábola do bom samaritano que não se prendeu a regras, mas que as desconheceu para socorrer o seu "próximo", indica a abertura que deveria ter o cristianismo e sua atenção para o que consideramos como apenas contingente (742). Mesmo que não consigamos viver sem regras e leis é importante não deixar que elas nos desumanizem. O núcleo de nossa vida espiritual deve se encontrar para além da norma, a qual pode, às vezes, ser por ele suplantada (743).

\section{Em diálogo com Charles Taylor}

\section{O cristão na sociedade secularizada}

A obra deste estudioso canadense se revela complexa por abranger diversas perspectivas de leitura como a sociológica, a histórica, a filosófica e a teológica, para só mencionar as principais. Um juízo exaustivo sobre a multiplicidade das idéias apresentadas se mostra assim como uma missão impossível. Resta-nos escolher alguns temas que nos parecem mais dizer respeito a uma ótica teológica e pastoral. Começaremos com a questão posta à fé do cristão na atual sociedade secularizada. Ninguém duvida mais que a hodierna sociedade pluralista seja um fato histórico irreversível. Não adianta sonharmos com épocas passadas que imaginamos mais perfeitas do que realmente foram. O respaldo social da fé individual desapareceu em grande parte e a própria sociedade dispensa a religião para se fundamentar. Houve 
uma mudança séria no que Taylor chama de "imaginário social". Vejamos como este fato tem um forte e decisivo impacto na fé do cristão.

Sabemos que a realidade não se oferece tal qual é, mas que sempre é atingida através da perspectiva com que a consideramos. Sabemos também que ela só responde às questões concretas que lhe pomos. Daí a pluralidade de leituras tão característica dos nossos dias, daí a diversidade das ciências, daí a busca atual pelo diálogo interdisciplinar e pela percepção global (holista) da realidade. Levando a sério esta inevitável participação subjetiva em toda abordagem objetiva da realidade, podemos afirmar que todo e qualquer conhecimento é interpretação, a saber, uma apreensão do real na perspectiva do sujeito. Este quadro interpretativo constitui o horizonte de compreensão do indivíduo que lhe é transmitido através de seu contexto sociocultural ou conseguido através do empenho pessoal, como o estudo diuturno ou a vivência em outro contexto vital. Só dentro deste horizonte ganham sentido as explicações da realidade, os valores socialmente aceitos e as práticas decorrentes de ambos. Portanto, a mudança de horizonte acarreta inevitavelmente tornar problemática a compreensão e as práticas da vida cotidiana do indivíduo.

Se tivermos em consideração que o cristianismo, como qualquer outra religião, vem a ser uma compreensão determinada da realidade, a saber, a visão cristã na perspectiva lançada por Jesus Cristo, que atuou não só como salvador, mas também como hermeneuta da humanidade, então já aparece a importância de um horizonte cristão para que os dados e as práticas da fé possam ser apreendidos e devidamente vividos pelo cristão. Este horizonte era oferecido pela cultura cristã nos séculos passados, reforçada pela aliança entre o altar e o trono. Este mesmo horizonte desapareceu no atual contexto sociocultural secularizado, caracterizado por Taylor como um quadro referencial imanente. Daí decorre que o cristão terá que professar e viver sua fé numa sociedade que se estrutura intencionalmente desconhecendo esta fé, bem como conviver com outros que não a partilham e mesmo a questionam por abraçarem cosmovisões e práticas diferentes.

Outro componente da situação contemporânea deve ser assinalado. O cristão acolhe sem mais alguns traços da atual cultura, como a valorização da subjetividade, da liberdade pessoal, da própria razão, da afetividade, da totalidade e da expressividade. Este fato inviabiliza qualquer tentativa de retorno à cristandade. Também explica a ineficácia das tentativas de solucionar o problema por meio da instituição eclesial, recorrendo seja à tradição seja à própria autoridade. Com outras palavras, apenas a Igreja, sozinha, não mais consegue configurar um horizonte de fé para o cristão, tal como acontecia num passado recente através das instituições católicas, sobretudo educativas. Pois o pluralismo cultural e religioso também já se encontra dentro das mesmas, constituindo um sério desafio para estas instituições em sua tarefa de transmissoras e educadoras da fé. Como sair deste impasse? 
Podemos prever (o que já vem acontecendo) que a situação atual provocará uma diminuição da população de cristãos apenas batizados e desprovidos de vivência e prática religiosa séria, que viviam tranqüilamente numa sociedade de cristandade. Não lhes bastará mais uma tintura superficial de religião e práticas devocionais festivas, quando não interesseiras. Podemos também antecipar que o cristianismo tenderá a acentuar mais o pessoal do que o institucional, olhando mais a pessoa concreta e menos a obra, respeitando o itinerário de cada um e evitando juízos gerais que desconsiderem a etapa histórica do indivíduo, fomentando ainda a participação de todos sem a qual não haverá uma comunhão real.

Embora não possamos separar hermeticamente o que recebemos do exterior e o que provém do nosso interior, já que tais mundos interagem continuamente, contudo se justifica acentuarmos mais nossa subjetividade em nossos dias. Pois os animais que não dispõem de uma proteção externa como as tartarugas, são dotados de uma estrutura óssea interna como os vertebrados. Se o horizonte externo se foi, nos restam os recursos internos. O primeiro deles é a própria experiência espiritual, como já observava Karl Rahner prevendo nossos dias. Podemos acrescentar a urgência de uma formação cristã adulta (pois a infantil é presa fácil da ciência moderna) que forneça internamente o quadro interpretativo cristão ausente da sociedade. Esta só poderá resultar numa fé realmente vivida se for oxigenada por um compromisso de vida. Não só missionário, como lucidamente afirma o Documento de Aparecida, mas em todo envolvimento concreto pelo outro mais necessitado ou excluído como concretização do amor fraterno e confirmação de uma fé não teórica, mas que chegou à vida.

\section{Tensões no cristianismo}

Taylor nota no cristianismo uma tensão entre os objetivos transcendentes do mesmo e as demandas mais imanentes por parte dos cristãos. Esta observação, aliás, vale para as demais religiões. No cristianismo o dilema é resolvido na época clássica com os monges se ocupando de Deus e os leigos se dedicando às tarefas terrestres. Para o autor a Reforma tentou resolver a questão colocando a todos no mesmo patamar, a saber, dedicando-se a Deus na vida cotidiana. Para isso rebaixou as elites cristãs (sacerdotes e religiosos). Na Igreja Católica a visão tradicional que criava duas classes desiguais de católicos devido a uma vocação à santidade específica, a saber, religiosos e seculares, terminou no Vaticano II já que todos são igualmente chamados a serem o Povo de Deus (LG 9-17). Naturalmente a igual dignidade de todos os cristãos não elimina as diferenças nos serviços (ministérios) internos da comunidade. Mas a conquista do Concílio implica na tomada de consciência desta verdade por todos os membros da Igreja, que é gradativa e que pode exigir muitos anos.

A tensão apontada pelo autor pode ser considerada sob outra perspectiva. Pois ela está na raiz da tentação espiritualista que acompanha o cristianis- 
mo. Dedicar a vida a Deus ou se entregar seriamente às tarefas provindas do mundo? O dilema reduziu bastante o alcance da mensagem evangélica, afastou a fé cristã da vida concreta e o cristianismo da sociedade e da cultura. Hoje temos consciência de que o dilema é falso porque o imperativo cristão ao nos levar ao outro necessitado nos compele a colaborarmos na construção da história, na organização da sociedade e na realização de uma humanidade solidária. Nada do que é humano é alheio à fé cristã. Esta compreensão integral do Reino de Deus não elimina, entretanto, a tensão em âmbito individual. Pois, no fundo é a ação do Espírito Santo que nos leva ao compromisso pelo mundo, em sentido amplo, que não se reduz só ao social, embora este seja o mais óbvio em nossos dias. Mas é preciso que esta verdade não seja esquecida em nossa ação, que perderia assim o que a especifica como tal e nos levaria a agir por outras motivações espúrias.

Outra fonte de tensão, na opinião do autor, está na busca por sacramentos e por sacramentais para curas físicas ou outros objetivos pessoais numa ótica de uso de meios "mágicos", relegando ao segundo plano seu sentido salvífico como sinais do amor de Deus. Sem dúvida este desvio aconteceu no passado e ainda pode ser encontrado hoje. Apesar da reserva por parte da ciência teológica, a religiosidade popular não o dispensa. Apesar da tendência do iluminismo de colocar a religião apenas na mente, realizando o que o autor chama de "excarnação", a religiosidade festiva volta sempre, ainda mais hoje com o pentecostalismo que une emoções intensas com curas milagrosas. De qualquer modo a questão mais teológica não é aventada pelo autor, a saber, o Transcendente se relaciona com o ser humano sempre através de sinais que respeitam sua transcendência e simultaneamente o tornam presente na história. Estes "sinais sagrados" devem remeter sempre ao que assinalam, só se tornando mágicos quando se absolutizam e deixam de ser sinais. Aliás, o tal desencantamento preconizado por Max Weber deveria mais propriamente ser denominado "desmagicização" do mundo. E permanece a questão se, de fato, a religiosidade popular se detém no sinal ou transcende-o numa postura cristã autêntica.

\section{Natural e sobrenatural}

Outro tema presente na grande síntese de Taylor concerne à gênese do quadro imanente da atual cultura enquanto foi também provocado pela distinção teológica de natural e sobrenatural. Nascida para justificar a liberdade da graça divina acabou sendo radicalizada no nominalismo para salvaguardar a soberania de Deus (vontade absoluta) diante das leis da natureza. Entretanto o efeito foi exatamente o contrário, pois o desencantamento da natureza então em curso acabou por limitar ao "natural" o âmbito da experiência humana banindo o sobrenatural da vida concreta. $\mathrm{O}$ advento da ciência moderna com sua racionalidade funcional termina o 
processo, atribuindo apenas à razão a constituição da ordem cósmica, da ordem social e da ordem moral.

O autor percebe a limitação do quadro imanente, alude a este fato em diversas partes da obra, mas não tenta (não era seu objetivo principal) uma reflexão de cunho mais teológico para a problemática. Naturalmente ela se revela bem complexa, mas não podemos deixar de indicar algumas grandes linhas para esclarecê-la. No que diz respeito à presença e atuação de Deus na natureza é necessário respeitar a transcendência de Deus que jamais poderá ser justaposta a qualquer realidade criada, bem como jamais poderá ser alcançada por qualquer ciência humana. Deus só pode ser vislumbrado enquanto a totalidade do universo criado grita em sua contingência para a razão de sua existência. E mesmo aí Deus permanece escondido, mistério para o ser humano. Mas nem por isso ausente já que é a razão última dos fenômenos diversamente abordados e explicados pelas múltiplas ciências criadas pela razão humana. Não deve ser imaginado como o fundamento de uma ordem impessoal, fruto da razão humana como pensava o deísmo, pois a mesma sofre continuamente a mudança dos paradigmas enquanto ordem cósmica e depende da historicidade da razão e da realidade contextual enquanto ordem social e moral.

Com relação à redução da experiência humana exclusivamente ao âmbito do "natural" também se impõe uma correção teológica, intuída por Taylor em várias páginas de seu livro, mas não devidamente refletida. Se partirmos da criação em Cristo como nos testemunha o Novo Testamento, então não mais podemos conceber uma antropologia impermeável e independente da realidade teológica. Já o percebera Santo Agostinho que não separa as duas ordens, já o compreendera Santo Tomás de Aquino que punha a felicidade do ser humano na visão beatífica, como demonstra Henri de Lubac em suas obras e como confirma o Concílio Vaticano II (GS 34). Daqui a reação de alguns teólogos em nossos dias (Radical Orthodoxy). Se tivermos presente que a nostalgia de Deus nasce do coração enquanto núcleo central da pessoa humana, no qual as faculdades ainda se encontram unidas, então a ação de Deus como mistério atinge a totalidade da mesma, iluminando-a com a sua luz e consolando-a com a sua paz, mesmo que esta não consiga traduzir esta ação em conceitos que fariam de Deus mais um objeto do conhecimento.

Observemos também que nesta ótica a presença atuante de Deus se faz sentir em meio às experiências humanas, cotidianas ou não. Importante é saber captar esta presença escondida, vislumbrada nas entrelinhas do texto de nossa vida. Assinalemos ainda que numa cultura desprovida de símbolos religiosos em seu espaço público as verdades e os valores propriamente cristãos tenderão a se tornar realidade, seja nas convicções, seja nas práticas de vida, também desprovidos de traços religiosos explícitos. São realizações do Reino de Deus, são acontecimentos salvíficos, embora apenas 
se manifestem como ações de solidariedade, de justiça, de compaixão, de busca da verdade, de luta pela liberdade, de respeito pelos direitos humanos. Perfeitamente aceitável se nos mantemos na ótica unitária de natureza e graça. Mas como o cristianismo, todo ele, constitui sinal salvífico do transcendente na história, já que não é o Reino de Deus acontecendo, cabelhe a tarefa de buscar novos sinais explicitamente cristãos que sejam pertinentes e significativos para as futuras gerações.

\section{Religião e sociedade}

Subjacente a toda a obra de Taylor está a relação entre cristianismo e sociedade civil. Suas observações sobre a diminuição da influência religiosa na esfera pública, da apropriação pelo Estado de ações de cunho caritativo e educativo, da nova situação do cristianismo diante do Estado Moderno que não mais necessita de uma fundamentação religiosa para se legitimar, da ordem social que se quer leiga independente de uma confissão religiosa, não deixam de recolocar a antiga questão da relação entre Igreja e Estado, ainda que a vejamos sob o prisma de religião e sociedade. A história nos ensina que uma separação total dos dois âmbitos jamais se deu totalmente. A clareza da distinção conceitual não consegue uma realização histórica que a comprove. Na tentativa mais radical de erradicação da religião feita pela revolução francesa, a sociedade civil voltou a criar novos símbolos "sagrados". Apesar do seu uso indevido, a expressão "dai a César o que é de César e a Deus o que é de Deus" (Mt 22,21) não justifica uma separação da esfera espiritual e da esfera temporal do ser humano.

De fato as conseqüências da separação são danosas para ambas as partes. É lugar-comum a acusação feita às religiões de serem fontes de conflitos no passado, sem ter em consideração os outros elementos aí implicados. Porém as violências perpetradas por regimes ateus no último século desmentem esta versão ingênua de que sem as religiões a humanidade viveria enfim em paz. As ideologias de todo tipo que ocupam o espaço deixado pelas religiões se revelaram ainda piores que as próprias religiões. Mas a questão permanece: qual o sentido da religião na sociedade?

Aqui também uma outra concepção corrente de religião deve ser corrigida, ao menos para o caso do cristianismo. Concebemos normalmente religião como uma realidade que vem dos tempos primordiais, uma tradição que fundamenta a cultura, os valores, o modo de vida de um grupo humano. As sociedades tradicionais viviam das tradições religiosas, fortemente responsáveis por sua organização social e garantia de sua fundamentação. Neste sentido o religioso atravessava todo o tecido social marcando sua presença atuante em todos os setores da vida. A sociedade moderna regida pela razão e apoiada nas conquistas das ciências tende a privar a religião de seu papel (e de seu sentido social) em nossos dias. Além disso, vivemos hoje numa sociedade pluri-religiosa que invalida de antemão desempe- 
nhar uma só tradição religiosa a função de lhe fornecer a razão última de sua unidade e de sua identidade. Porém pode o cristianismo se ver incluído em tal definição de religião?

À primeira vista parece que sim, pois a fé cristã confessa um Deus criador de toda a realidade, portanto um Deus que tudo abrange, sem estar limitado a um território, a uma época, a uma etnia, a uma cultura. Este universalismo, entretanto, não pode ser utilizado para justificar ou fundamentar qualquer organização social. Pois Deus se revela conservando sua transcendência, o que veta a confecção de qualquer imagem sua que servisse a esta ou àquela particularidade, a esta ou àquela sociedade ou cultura. Tanto uma idéia simplista da providência divina como uma concepção deísta não encontra respaldo no Deus do cristianismo. Então nenhum relacionamento é possível com a sociedade?

Hoje já se reconhece que as religiões têm algo a oferecer à sociedade civil. São elas que denunciam a marginalização a que são condenados os mais pobres bem como as injustiças de políticas econômicas. São elas que oferecem uma esperança que sustenta e mobiliza os mais fracos. São elas que, livres de um dogmatismo doutrinário e impositivo, oferecem motivações e intuições substantivas (e não apenas funcionais) para as questões sujeitas ao debate público. São elas que, numa sociedade neoliberal e prisioneira de uma racionalidade funcional em busca de resultados, desmascaram a frieza burocrática e tecnocrática apontando os efeitos devastadores de certas decisões. São elas que, para além das macro-soluções milagrosas, apontam para a responsabilidade de cada um e para a imprescindível rejeição de um individualismo cômodo, sem as quais a ética na vida pública ou o problema ecológico não serão solucionados. Aqui a sabedoria religiosa talvez possa ser mais eficaz do que muitos discursos dos tecnocratas.

\section{Cristianismo e sociedade}

Estas reflexões provocadas pela obra de Charles Taylor não deixam de sugerir para o futuro uma nova relação entre o cristianismo e a sociedade. De fato, tudo pesado, não podemos ser pessimistas com relação à situação do cristianismo no mundo atual, ao contrário do que afirma a então vigente sociologia da secularização. Mas urge claramente uma mudança na presença e na atuação do mesmo numa sociedade futura, mudança esta que não deixará de afetar a própria instituição eclesial em sua configuração. Vejamos.

Jesus anuncia e faz irromper em sua pessoa o Reino de Deus que se distingue claramente dos reinos deste mundo, embora ele esteja presente na história. Pois se realiza no amor e na paz, no perdão e na renúncia, na compaixão e no compromisso pelo pobre. Não utiliza instrumentos de poder ou astúcias da política. Mesmo enquanto gera uma comunidade de 
homens e mulheres ou se estrutura como instituição não se encaixa em qualquer instituição política. De fato, o cristianismo é uma realidade sui generis apesar da diuturna tentação de acomodá-lo aos modelos sociais, culturais e institucionais dominantes na sociedade como comprova sua história, apesar de procurarmos fixá-lo numa configuração passada e ultrapassada como experimentamos em nossos dias. Contudo nenhuma configuração humana conseguirá traduzir a dimensão social deste Reino porque ele transcende a todas elas.

Este fato gera uma tensão entre o cristianismo e a sociedade, não como aquela erradamente imaginada no passado entre duas sociedades perfeitas que se enfrentavam, mas como uma presença que abre a própria sociedade para valores transcendentes, muitas vezes por ela esquecidos ou desvalorizados. Naturalmente desde que o cristianismo não se volte exclusivamente para si próprio limitando-se apenas ao culto, à espiritualidade ou à própria organização interna. Porque a sociedade civil pode se tornar presa de ideologias totalitárias, prisioneira da lógica de resultados ou do sistema econômico dominante, ela necessita uma instância que a transcenda e a questione, que a desestabilize beneficamente e que a faça progredir.

Aqui aparece o papel do cristianismo na sociedade futura. Não mais um poder paralelo que com ela concorra utilizando até métodos não evangélicos, mas proclamando uma mensagem dinâmica que a inquiete, a desinstale e a interpele. Experimentamos hoje quão importante é sua atuação no espaço público ao alertar a sociedade para o respeito à pessoa humana ou para a solidariedade universal, referências fundamentais para as questões da bioética ou da justiça no mundo. A mensagem cristã é prenhe de esperança por se abrir a um futuro que deixa para trás as limitações e misérias deste mundo, por injetar motivação e ânimo em face de cenários desanimadores, por garantir uma vitória futura demonstrando assim que a ética da responsabilidade não pode dispensar a ética da convicção. Presença atuante que deve se fazer sentir em todos os setores sociais, não como uma religião oficial ou mesmo como uma religião civil que fundamentasse uma sociedade, presença não alicerçada no poder ou no prestígio, mas na força da verdade, na mística da caridade, na opção da liberdade. A serena análise de Taylor conclui que os habitantes da sociedade secularizada demonstram nostalgia pelo transcendente e não se conformam ao confinamento que lhes é imposto pela atual cultura.

\section{Nova configuração eclesial}

Ao longo destas linhas não nos foi possível, e nem mesmo foi nossa preocupação, separar o discurso sobre o cristianismo de uma reflexão mais específica sobre a Igreja Católica. O mesmo acontece na obra de Taylor com relação às Igrejas nascidas da Reforma. Mas não poderíamos concluir esta exposição sem indicar, ao menos, alguns traços que deverão marcar a 
configuração eclesial no futuro. São já numerosas as publicações sobre este tema. Pretendemos simplesmente expor algumas reflexões que nos ocorreram por ocasião da leitura desta obra. Observemos, de antemão, que as mudanças se fazem mais facilmente na ordem da reflexão doutrinal do que no âmbito da estrutura institucional, pois esta última pesa bem mais do que pensamos na socialização religiosa do indivíduo e, portanto, na sua identidade religiosa. Daí a resistência oferecida. Muda-se mais facilmente de idéias do que de modos de vida. Outros fatores que dificultam uma evolução institucional poderiam ser: a tendência das instituições a se autoperpetuar uma vez nascidas, a defesa tenaz das estruturas de poder já estabelecidas, o desgaste de forças e energias para implantar algo novo, a segurança tranqüila de manter o tradicional.

A configuração atual da Igreja Católica tomou, em grande parte, seu modelo da sociedade hierárquica medieval, com suas ordens e classes sociais bem definidas. Nada de mais, pois a identidade teológica da comunidade cristã nascida do Novo Testamento deve encontrar sua expressão institucional no contexto histórico e sociocultural onde se encontra. Já as comunidades paulinas da diáspora aparecem diferentes da comunidade de Jerusalém. Podemos mesmo observar como o próprio modo de concretizar o governo na Igreja dependeu em grande parte do modo como era governada a cidade de Roma, o que nos parece muito natural. O problema se põe quando uma configuração que se mostrou adequada no passado se torna retrógrada no presente devido às mudanças experimentadas pela sociedade. Neste ponto reside o núcleo da atual crise da Igreja. $\mathrm{O}$ esforço teológico desenvolvido por ocasião do Concílio Vaticano II, ainda que sujeito a compromissos em prol da unidade, não se impôs no âmbito institucional no período pós-conciliar gerando tensões e conflitos.

A eclesiologia de comunhão não conseguiu uma correspondente expressão institucional, a participação ativa dos fiéis se vê cerceada por restrições e cautelas, os cargos eclesiásticos continuam a serem vistos como instâncias de poder e não tanto como carismas de serviço, a colegialidade episcopal permanece um sonho diante da resistência centralizadora da cúria romana, o novo clero considera o serviço sacerdotal como uma carreira eclesiástica, a desconfiança das autoridades com relação à pastoral com os mais pobres esfriou bastante o empenho social e a mística profética de muitos católicos, o rígido controle da reflexão teológica por parte da hierarquia resultou no atual enfraquecimento da produção teológica (embora também motivada por outros fatores, como a insuficiente formação do clero que repercute nos quadros do próprio episcopado). Temos que voltar à intuição-mestra do Concílio Vaticano II, a saber, atualização (aggiornamento) e diálogo, sendo que um não acontece sem o outro.

Para isto necessita a Igreja seguir mais de perto o seu Mestre, que sempre rejeitou o poder temporal e para o qual a maior responsabilidade na comu- 
nidade equivalia a um maior serviço (Mc 10,41-45). Institucionalmente esta característica da fé cristã veta à Igreja se apresentar como um poder com os mesmos recursos e os mesmos métodos dos poderes deste mundo, bem como usar do mesmo para sua ação evangélica de difundir a mensagem salvífica de Jesus Cristo. Devemos virar de vez a página histórica da cristandade que não foi tão cor-de-rosa como aparece para muitos, devemos reaprender a lutar pelo Reino como o fez Jesus Cristo, no testemunho de vida, na pobreza, na humildade, no escondimento, na ausência palpável de resultados, sem se escravizar a uma lógica funcional ou a um culto à eficácia, e menos ainda aos poderosos deste mundo.

A atual sociedade se caracteriza pela inevitável coexistência das diferenças que exige uma unidade que respeite e acolha em seu seio tal pluralidade. O mesmo vale para a Igreja por se encontrar nesta sociedade, por abrigar etnias, culturas, mentalidades religiosas diversas. A fé cristã transcende qualquer particularidade, de qualquer gênero que seja. Pelo contrário, ela convoca todas elas a viver a aventura da existência de Jesus Cristo. A diversidade só pode enriquecer a unidade, assim como a uniformidade só pode empobrecê-la. A urgente inculturação da fé, proclamada no início do pontificado de João Paulo II e posteriormente cerceada, deve ser fortemente retomada pelas Igrejas Locais, presença atuante da Igreja de Jesus Cristo animada pelo Espírito Santo nos mais variados rincões deste planeta. Expressões doutrinais, celebrações litúrgicas, práticas pastorais, organização eclesial devidamente inculturadas permitiriam que a Igreja desvelasse com mais verdade o que ela realmente é, a saber, sacramento (sinal) da salvação de Deus.

Também certas conquistas da modernidade, algumas delas inspiradas pelo próprio cristianismo como o valor da pessoa, o respeito à liberdade individual, os direitos humanos, a justiça social, a cidadania consciente, a participação na construção da sociedade, o espaço público, não poderão estar ausentes na Igreja, respeitada naturalmente sua índole própria, sob pena de se ver rejeitada pelas populações futuras. Este dado novo implica na criação de algumas instituições de escuta e de diálogo, de outras de participação e de decisão. Todo o Povo de Deus deve se ver envolvido (e não tratado como massa passiva e sem voz), o que exige uma outra mentalidade por parte da hierarquia.

Se a vida e a pregação de Jesus Cristo foi toda ela preferencialmente voltada para os mais pobres e excluídos, então também o Reino de Deus é destinado primeiramente para eles. Este fato é dado de revelação (assim agiu Deus, assim é Deus), este fato deve ser levado a sério pela Igreja, sinal do Reino em sua vida e em sua proclamação. A Igreja deve ser a Igreja dos pobres, que nela devem se sentir em sua casa. Não o será sem uma profunda conversão espiritual de seus responsáveis que leve a mudanças estruturais, a um gênero de vida mais simples, a uma maior proximidade 
com os últimos deste mundo, a um apoio real àqueles e àquelas que se envolvem com os sem voz e sem vez com grandes renúncias e mesmo com risco de vida. Uma maior modéstia institucional só a fará ganhar maior credibilidade e irradiação junto à sociedade.

Não pretendemos uma abordagem completa e profunda de toda esta questão, mas só apresentarmos algumas reações provocadas pela leitura da obra de Charles Taylor. Sem dúvida alguma estamos às vésperas de sérias transformações no cristianismo, algumas das quais já foram afirmadas no Concílio Vaticano II. Importa urgir que as mesmas sejam realmente implantadas e, se necessário, atualizadas. $\mathrm{O}$ cristianismo não pode ficar prisioneiro de um momento histórico que pode oferecer segurança, mas que se revela estéril. Ele não se fundamenta nas conquistas do passado nem nas tradições que nos legaram. Ou talvez sejamos homens de pouca fé e nos falte uma autêntica confiança em Deus.

Mario de França Miranda SJ é doutor em teologia pela Pontifícia Universidade Gregoriana (Roma). Atualmente é professor de teologia sistemática na Pontifícia Universidade Católica (Rio de Janeiro). Foi membro da Comissão Teológica Internacional (Roma). Publicou entre muitos livros e artigos: Um catolicismo desafiado: Igreja e pluralismo religioso no Brasil, São Paulo: Paulinas, 1996; O cristianismo face às religiões, São Paulo: Loyola, 1998; A salvação de Jesus Cristo: A doutrina da graça, São Paulo: Loyola, 2004; A Igreja numa sociedade fragmentada, São Paulo: Loyola, 2006; e Aparecida: a hora da América Latina, São Paulo: Paulinas, 2007.

Endereço: R. Marquês de São Vicente, 389

22451-041 Rio de Janeiro - RJ

e-mail: mfranca@puc-rio.br 


\section{COLEÇÃO CES}

A Coleção CES reúne estudos de filosofia e cultura, teologia e religião, sob a responsabilidade da Faculdade Jesuíta de Filosofia e Teologia de Belo Horizonte.

\section{TÍTULOS PUBLICADOS:}

1. A Palavra se fez livro (Johan Konings)

2. Cenários da Igreja, $2^{a}$ ed. (J. B. Libanio)

3. Teologia da espiritualidade cristã (Danilo Mondoni)

4. Igreja contemporânea - encontro com a modernidade (J. B. Libanio)

5. Conhecimento afetivo em Santo Tomás (Paulo Meneses)

6. Experiência mística e filosofia na tradição ocidenta (Henrique $C$. de Lima Vaz)

7. História da Igreja na Antiguidade (Danilo Mondoni)

8. Matrimônio - Aliança - Reino (Francisco Taborda)

9. Ecologia e criação - Resposta cristã à crise ambiental (José Roque Junges)

10. A arte de formar-se (João Batista Libanio)

11. Folhas de Outono (Fernando Bastos de Ávila)

12. Deslocamentos da teologia - mutações do cristianismo (Carlos Palacio)

13. Um incendido desejo das Índias (Marina Massimi)

14. Teologia em diálogo (Bruno Forte)

15. Filosofia e método (Emídio Fontenele de Brito / Luiz Harding Chang - orgs.)

16. Teologia e Pastoral (Johan Konings)

17. Filosofia e Política (Miriam Campolina D. Peixoto / Washington da Silva Paranhos - orgs.)

18. Mysterium Paschale - A quenose de Deus segundo Hans Urs von Balthasar (Clarita Sampaio Mesquita Ribeiro)

19. Existência cristã hoje (Mario de França Miranda)

20. Linguagem \& Liguagens (João A. Mac Dowell, SJ / Marcelo Yukio Yamamoto, SJ - orgs.)

\section{COLEÇÃO FAJE}

\section{TÍTULOS PUBLICADOS:}

1. Doctor Amoris Causa (Cláudio Paul - org.)

2. Imaginação simbólica (Marco Heleno Barreto)

Edições Loyola - Cx. P. 42.355 - CEP 04299-970 São Paulo

e-mail: vendas@loyola.com.br 